\title{
Reconnaissance on the suitability of the available water resources for irrigation in Thakurgaon District of northwestern Bangladesh
}

\author{
Mohammad Amir Hossain Bhuiyan • \\ Samuel Ganyaglo $\cdot$ Shigeyuki Suzuki
}

Received: 24 November 2013/Accepted: 26 March 2014/Published online: 26 April 2014

(C) The Author(s) 2014. This article is published with open access at Springerlink.com

\begin{abstract}
Reconnaissance on the suitability of the available groundwater resources for irrigation in Thakurgaon District of northwestern Bangladesh was done by determining $\mathrm{pH}$, TDS, EC, hardness, alkalinity, major cations and anions. The $\mathrm{pH}$ values suggest that the water is slightly acidic to strongly basic. The dominant cation and anion in the study area are $\mathrm{Ca}^{2+}, \mathrm{Mg}^{2+}$ and $\mathrm{HCO}_{3}{ }^{-}$, respectively. Calcium bicarbonate, calcium-magnesium-bicarbonate and calcium carbonate are the dominant hydrochemical facies among the water samples. The groundwater system in the study area may be recharged through infiltration of rain. The above statement is further supported by Gibbs plot where most of the samples fall within the rock-dominance zone. The evolution of these waters may be controlled by precipitation and dissolution of carbonate minerals. The USSL, SAR-EC classification schemes and Wilcox plot confirm that the groundwater samples are good to excellent as irrigation water. However, the groundwater evolution in this study is mainly the result of weathering of carbonate minerals and cation exchange within the aquifer materials, confirming the shallow porous groundwater hydrochemistry characteristics.
\end{abstract}

M. A. H. Bhuiyan · S. Suzuki

Department of Earth Sciences, Okayama University, 1-1,

Tsushima-Naka 3 Chome, Okayama 700-8530, Japan

M. A. H. Bhuiyan ( $\square)$

Department of Environmental Sciences, Jahangirnagar

University, Dhaka 1342, Bangladesh

e-mail: amirhb75@yahoo.com

S. Ganyaglo

National Nuclear Research Institute, Ghana Atomic Energy

Commission, P.O. Box LG 80, Legon, Accra, Ghana
Keywords Hydrogeochemical character - Groundwater · Irrigation water quality · GIS · Bangladesh

\section{Introduction}

Groundwater quality is important for determining its use for domestic, irrigation and industrial purposes. It is however, degraded by several factors related to human activities and geochemical changes. In floodplain areas degradation generally occurs owing to hydrogeochemical processes, arsenic contamination, aerosols deposited on the top soil and interaction of groundwater with brines and sedimentary formation (Sanford et al. 2007). Hydrogeochemical processes that are responsible for changing the chemical composition of groundwater differ due to variation of time and space. In fact, interaction of groundwater with aquifer minerals significantly influences the groundwater chemistry. However, the study of hydrogeochemical processes of the groundwater system helps to obtain the contributions of rock/soil-water interaction in aquifer. The geochemical processes are responsible for the spatio-temporal variations in groundwater chemistry (Kelly 1940; Wilcox 1948; Matthess 1982; Kumar et al. 2006). Apart from the natural process, anthropogenic contaminations such as industrial effluents, agrochemicals, municipal wastewater, septic tank effluent and landfills are other major sources of water quality deterioration (Mondal et al. 2008, 2011; Selvam et al. 2013).

About one billion people are directly dependent upon groundwater resources in Asia alone (Foster 1995). The dependence on groundwater has increased tremendously in recent years in many parts of arid and semi-arid regions because of the changes of monsoon and the scarcity of surface water. Even though the quantity and quality of 
groundwater available for irrigation are variable from place to place in India and Bangladesh, many groundwater exploitation schemes in developing countries such as Bangladesh are designed without proper attention to quality issues.

In addition, due to interruption of trans-boundary river courses (Ganges and Tista rivers) of Bangladesh in the Indian corridor, the water flow in Bangladesh territory hampered significantly. Recently, there occurs some shortage of surface water for irrigation. Therefore, the agricultural activities in the northwestern part of the country face huge scarcity of surface water, and the people mostly depend on groundwater systems. This water crisis has been increased tremendously in the northern part of Bangladesh. The relative dependence on groundwater for irrigation in Bangladesh has notably increased with time. During 1969-1970, groundwater had been used only about $3.0 \%$ of the total of 1.1 million irrigated hectares. However, 10 years later (i.e., in 1979-1980), the share of groundwater in the total irrigation activities had risen to $11.5 \%$ when the total irrigated acreage grew to 1.60 million hectares (Bhuiyan 1984). However, recently this amount has been raised up to $30 \%$ compared to the previous consumption. For that reason, it is necessary to know the hydrogeochemical characteristics of groundwater of the aquifer system and know how much suitable is this water for irrigation purposes. Previous studies on groundwater related issues in Bangladesh have not been focused sufficiently on irrigation purposes. The main objectives of the present research are to carry out the reconnaissance of groundwater quality in Thakurgaon District of northwestern Bangladesh for irrigation purposes. It is also intended to show the spatial distribution of hydrogeochemical constituents for selecting suitable irrigation schemes.

\section{Geology and hydrogeology of the study area}

The study area is a part of Tista Fan, located in the northwestern part of Bangladesh. It lies between $25^{\circ} 54^{\prime} \mathrm{N}$ to $26^{\circ} 12^{\prime} \mathrm{N}$ and $88^{\circ} 18^{\prime} \mathrm{E}$ to $88^{\circ} 38^{\prime} \mathrm{E}$ (Fig. 1). It is the extension of the Himalayan piedmont plain that slopes southward from a height of 96-33 m with a gradient of about $55 \mathrm{~cm} / \mathrm{km}$. The region consists of piedmont sand, gravel at the base, fine sand and silt at the top. These were deposited as alluvial fan of the Tista, Mahananda and Karatoya River. The distributaries of these rivers originate from the Terai area of the foothills of Himalayas. There was a major shift in the courses of these rives in 1887 (LGRD 2002). In the northwest, a part of the delta has been classified as inactive. However, a major part in the south and southeast is very active by Tista and Brahmaputra River. In the Tista fan, major aquifer systems belong to the
Late Pleistocene to Holocene sediments. Most of the groundwater withdrawn for domestic or agricultural purposes in the Barind Uplands areas is from the Dupi Tila Sandstone. Parts of the Tista Fan area in northern Bangladesh (Fig. 1) and the Piedmont area along a narrow strip of the hills of the greater Mymensingh and Sylhet districts also withdraw all water from sediments older than Late Pleistocene. In all the groundwater studies undertaken in Bangladesh, the aquifer systems have not been divided stratigraphically. Conceptual models of hydrogeological conditions, based on simple lithology and depth rather than stratigraphic units, have been used to assess the engineering and hydraulic properties of aquifers and deep tube well designs at depth of $150 \mathrm{~m}$ (LGRD 2002).

\section{Methodology}

\section{Sample Collection}

Twenty-five groundwater samples (one at each well) were collected from the shallow tube wells and irrigation pumps (depths of wells are approximately 90-120 m) during winter season in Thakurgaon Sadar Thana of Thakurgaon district in Bangladesh following the standard procedures of Bhattacharya et al. (2002). The geographic positions of the sample sites were recorded by GPS (Explorist model: 200). The stagnant water in the hand-dug wells was pumped out for $15 \mathrm{~min}$ prior to sample collection. The pre-sterilized plastic bottles were washed three times with sample water. The samples were collected after filtering through $0.45-\mu \mathrm{m}$ filters and acidified with $\mathrm{HNO}_{3}$ for trace elements analysis. However, the samples collected for bicarbonate and major ions analysis were filtered but not acidified.

Physicochemical parameters and elemental analyses

Physicochemical parameters were measured using available field kits. The $\mathrm{pH}$ of water samples was determined using microprocessor $\mathrm{pH}$ meter (HANNA Instruments model: pH 211). Electrical conductivity (EC) was measured using conductivity meter (HANNA Instruments model: HI 8033). Microprocessor turbidity meter (HANNA Instruments model: HI 93703) was used for recording spot turbidity. Alkalinity was determined using titrimetric method. Anions $\left(\mathrm{SO}_{4}{ }^{2-}, \mathrm{PO}_{4}{ }^{3-}, \mathrm{Cl}^{-}\right.$and $\left.\mathrm{NO}_{3}{ }^{-}\right)$were measured following the standard procedures of Michael (1975). Fluoride concentrations were measured by $\mathrm{F}^{-}$electrode using the EPA standard method 430.2 for fluoride measurement (Skoog and Leary 1992).

Elemental analysis was performed by a Perkin-Elmer Atomic Absorption Spectrophotometer (AAS: Model 3110). The accuracy and precision of the AAS method 
Fig. 1 Map showing the sample locations and surface geology of the study area

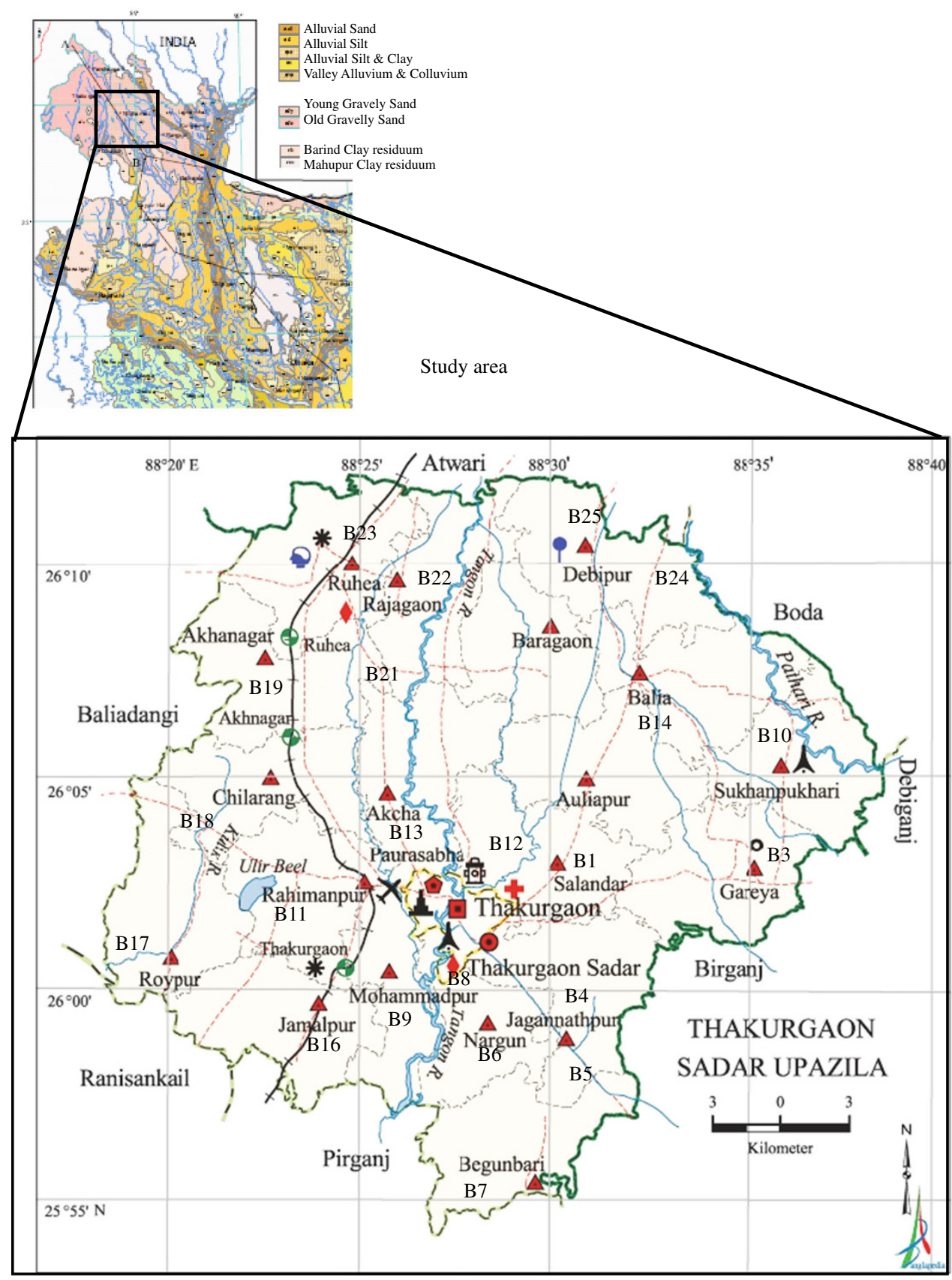

were verified by triplicate analyses of NIST standard reference material, SRM-1640. The precision was better than $8 \%$ for all analyzed elements. The instrumental detection limits (IDL) (in $\mathrm{mg} / \mathrm{l}$ ) of heavy metals in the analyzed samples were: $0.05(\mathrm{~K}), 0.03(\mathrm{Ca}), 0.1$ (Ti, V, Cr, Ni, Cu, $\mathrm{Pb}), 0.01(\mathrm{Mn}), 0.038(\mathrm{Fe})$, and $0.026(\mathrm{Zn})$. An Orion AAS (Model: AA240) coupled with a hydride generation system was used for arsenic analysis. The IDL of arsenic was $0.1 \mathrm{mg} / \mathrm{l}$ and precision was $5 \%$. Bore logs of the respective wells were collected from the Bangladesh Government local branch of public health engineering and irrigation extension office.
Methods for hydrochemical and water quality evaluation

The total hardness (TH) in ppm (Todd 1980; Hem 1985; Ragunath 1987) was determined by following equation: $\mathrm{TH}=2.497 \mathrm{Ca}^{2+}+4.115 \mathrm{Mg}^{2+}$. The $\mathrm{Na} \%$ is computed as equation:

$\mathrm{Na} \%=\frac{\mathrm{Na}}{\mathrm{Na}+\mathrm{Ca}+\mathrm{Mg}} \times 100$.

where the concentrations of the individual species are in milli-equivalents per liter. The RSC is computed taking the 
alkaline earths and weak acids in milli-equivalents per liter (Rao et al. 2012) as follows (Ragunath 1987): $\mathrm{RSC}=\left(\mathrm{HCO}_{3}{ }^{-}+\mathrm{CO}_{3}{ }^{2-}\right)-\left(\mathrm{Ca}^{2+}+\mathrm{Mg}^{2+}\right)$. The permeability index (PI) indicated suitability of groundwater for irrigation, as the soil permeability is affected by long-term use of irrigation water, influenced by the $\mathrm{Na}^{+}, \mathrm{Ca}^{2+}, \mathrm{Mg}^{2+}$, and $\mathrm{HCO}_{3}{ }^{-}$contents of the soil. For assessing the suitability of water for irrigation, Doneen (1964) and Ragunath (1987) evolved a criterion based on PI where water can be classified classes I, II, and III. The PI can be written as follows: $\mathrm{PI}=\left(\mathrm{Na}^{+}+\sqrt{ } \mathrm{HCO}_{3}\right) \times 100 /\left(\mathrm{Ca}^{2+}+\mathrm{Mg}^{2+}+\right.$ $\mathrm{Na}^{+}+\mathrm{K}^{+}$), where the concentrations are reported in milliequivalents per liter.

For evaluating the water quality for irrigation purpose, the sodium or alkali hazard expressed by sodium adsorption ratio (SAR) is widely used (Devadas et al. 2007; Simsek and Gunduz 2007). If water sample is high in $\mathrm{Na}^{+}$ and low in $\mathrm{Ca}^{2+}$, the ion exchange complex may become saturated with $\mathrm{Na}^{+}$which destroys the soil structure (Todd 1980). The SAR value of irrigation water quantifies the relative proportion of $\mathrm{Na}^{+}$to $\mathrm{Ca}^{2+}$ and $\mathrm{Mg}^{2+}$ and is computed as:

$$
\mathrm{SAR}=\frac{\left[\mathrm{Na}^{+}\right]}{\sqrt{\frac{\left[\mathrm{Ca}^{2+}\right]+\left[\mathrm{Mg}^{2+}\right]}{2}}}, \text { where }\left[\mathrm{Na}^{+}\right],\left[\mathrm{Ca}^{2+}\right] \text { and }\left[\mathrm{Mg}^{2+}\right]
$$

are defined as the concentrations of $\mathrm{Na}, \mathrm{Ca}$ and $\mathrm{Mg}$ ions in water, respectively (Ayers and Westcot 1985). In this equation, the concentrations are expressed as milli-equivalents per liter and are computed by dividing the aqueous concentrations of the corresponding ion expressed in milligrams per liter by the product of its atomic weight and the ionic charge (Simsek and Gunduz 2007). A combined ECSAR criterion is usually used to assess the potential infiltration hazard that might develop in a soil. Water with $\mathrm{EC}<700 \mu \mathrm{S} / \mathrm{cm}$ is said to be good irrigation water. The EC values of the analyzed samples vary from 129 to $288 \mu \mathrm{S} / \mathrm{cm}$ and are within the acceptable range. SAR values range from 0.064 to 0.274 and are within the acceptable range.

\section{Techniques for spatial analysis}

Kriging in one form or another is becoming a standard practice for local estimation in regional surveys of the environment, generally, and in hydrogeology, in particular (Gaus et al. 2003). It is a group of geostatistical techniques employed to interpolate the value of a random field at an unobserved location from observations of its value at nearby locations. Kriging provides the best linear unbiased estimation for spatial interpolation. However, it is widely known that the key tool of most geostatistical analyses is the variogram. The variogram can be described as half the expected squared difference between paired random functions separated by the distance and direction vector. The important features of the variogram are range, sill, and nugget effect. The variogram function can be expressed as follows:

$\hat{\gamma}(h, x)=\frac{1}{2 m(h)} \sum_{i=1}^{m(h)}\left[Z\left(x_{i}\right)-Z\left(x_{i}+h\right)\right]$

where $m(h)$ is number of pairs observations, $\mathrm{Z}\left(x_{i}\right)$ represents the regionalized variable at position $x_{i}$. For the traditional variogram, which is a function of one variable $h$, the model for the variogram can be acquired by the use of mathematical models for instance exponential, spherical, Gaussian, and linear variogram. These models may be fitted to the variogram, and the coefficients of the model may be employed to assign optimal weights for interpolation using kriging. In this study the applied form of kriging is ordinary kriging, which assumes an unknown constant trend: $\mu(x)=\mu$. In this case, the estimate method is linear weighted moving averages of the $n$ available observations. The interpolation by ordinary kriging is given by:

$$
\begin{array}{r}
\hat{Z}=\left(x_{0}\right)=\sum_{i=1}^{n} \lambda_{i} Z\left(x_{i}\right) \\
\sum_{i=1}^{n} \lambda_{i}=1
\end{array}
$$

where $\hat{\mathrm{Z}}\left(x_{0}\right)$ is estimated the value at $x_{0}$, and the kriging weights of ordinary kriging fulfill the unbiasedness condition. The weighting factors can be determined by solving a non-linear optimization problem involving the minimization of the estimated error to the constraint using the Lagrange multiplier (Shyu et al. 2011).

\section{Results and discussions}

\section{General hydrochemistry}

Statistics of the various hydrochemical parameters are presented in Table 1. The $\mathrm{pH}$ of the groundwater has a wider range varying from slightly acidic (6.21) to strongly alkaline (12.2). Elevated $\mathrm{pH}$ levels beyond the permissible limit ( $\mathrm{pH} 8.5$ ) occur only in samples B5, B6 and B23 which are evident by carbonate content in the borehole rocks. However, the $\mathrm{pH}$ value of water is controlled by the amount of dissolved $\mathrm{CO}_{2}, \mathrm{CO}_{3}{ }^{2-}$ and $\mathrm{HCO}_{3}{ }^{-}$concentrations. The EC varies from 134 to $295 \mu \mathrm{S} / \mathrm{cm}$ with a mean of $203.5 \mu \mathrm{S} / \mathrm{cm}$ with the standard deviation of 37.72 (Table 1). However, EC of the groundwater samples in this study is generally low and below the WHO (2004) stipulated maximum permissible limit $(1,500 \mu \mathrm{S} / \mathrm{cm})$ for drinking and domestic purposes. This is attributable to low content of dissolved ions in the groundwater. The TDS 


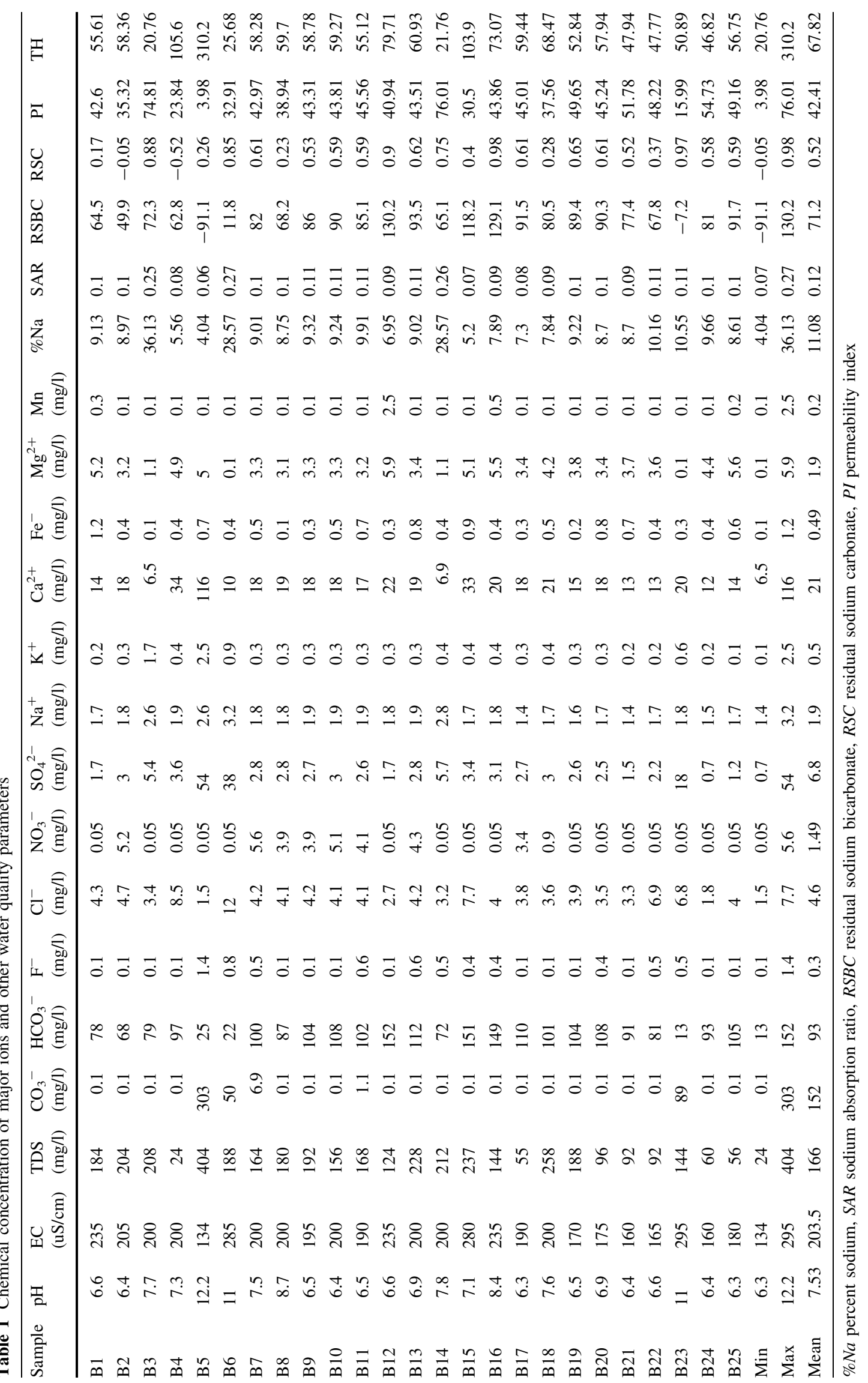


values range from 24 to $404 \mathrm{mg} / \mathrm{l}$ with a mean of $165.64 \mathrm{mg} / \mathrm{l}$, which exhibit the similar picture of EC. Freeze and Cherry (1979) also stated that TDS values of groundwater within the range of $0-1,000 \mathrm{mg} / \mathrm{l}$ are considered as fresh. On the basis of EC and TDS, groundwater samples in the study area falls on fresh group. The dominant cation in the area is $\mathrm{Ca}^{2+}$ and varies from 6.5 to $116 \mathrm{mg} / \mathrm{l}$ with a mean value of $21 \mathrm{mg} / \mathrm{l} . \mathrm{HCO}_{3}{ }^{-}$, the dominant anion concentration varies from 13 to $152 \mathrm{mg} / \mathrm{l}$ with a mean of $93 \mathrm{mg} / \mathrm{l}$. The dominance of this ion in the groundwater samples indicates that the rocks in the aquifer area are composed of carbonate minerals notably calcite, dolomite and gypsum. The $\mathrm{Na}^{+}, \mathrm{Mg}^{2+}, \mathrm{K}^{+}, \mathrm{Cl}^{-}, \mathrm{SO}_{4}{ }^{2-}$ and $\mathrm{CO}_{3}{ }^{2-}$ occur in very low concentrations. However, high $\mathrm{Ca}^{2+}$ and $\mathrm{CO}_{3}{ }^{2-}$ concentrations in groundwater samples imply a predominant calcite mineral in the aquifer that is being tapped. The range of $\mathrm{NO}_{3}{ }^{-}$is $0.05-5.6 \mathrm{mg} / \mathrm{l}$ with the mean value of $1.49 \mathrm{mg} / \mathrm{l}$ falling below the FAO (1972) standard limits. Fluoride ion varies from 0.1 to $1.4 \mathrm{mg} / \mathrm{l}$ with a mean of $0.49 \mathrm{mg} / \mathrm{l}$. The $\mathrm{F}^{-}$concentrations are generally low with respect to WHO (2004) limit of $1.5 \mathrm{mg} / \mathrm{l}$. However, the content of $\mathrm{F}^{-}$indicates the presence of fluorite mineral in the aquifer. Fe varies from 0.11 to $1.22 \mathrm{mg} / \mathrm{l}$ with a mean value of $0.55 \mathrm{mg} / \mathrm{l}$. Most of the samples show elevated Fe concentrations which is above the WHO (2004) recommended value of $0.3 \mathrm{mg} / \mathrm{l}$.

\section{Geochemical classification}

The values obtained from the groundwater samples are plotted on Piper (1944) trilinear diagram (Fig. 2) to

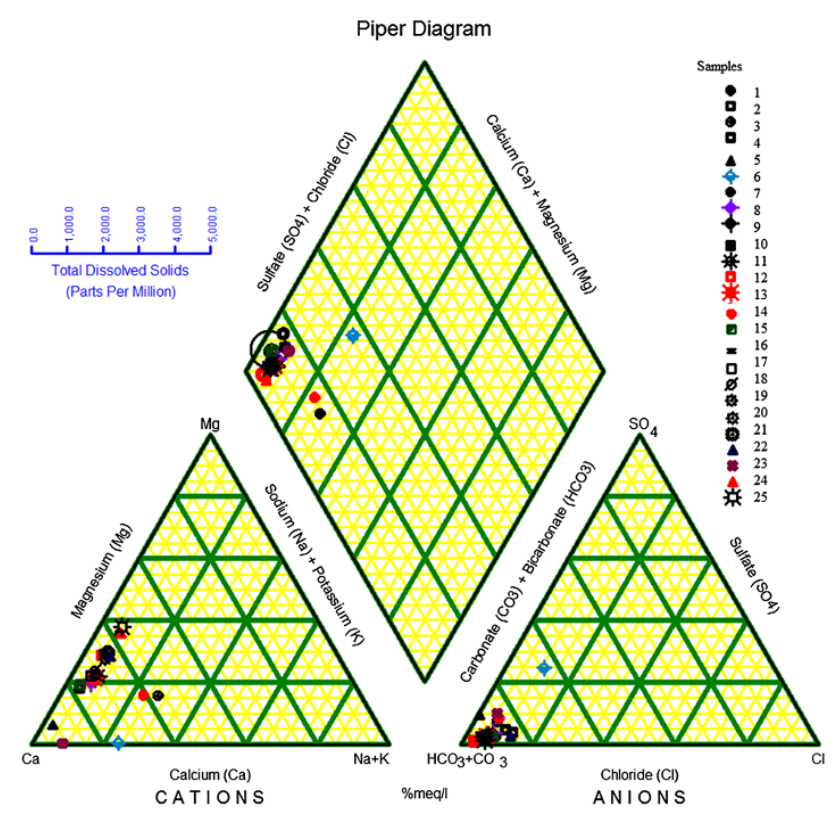

Fig. 2 The Piper (1944) diagram for the groundwater samples of the study area recognize the hydrogeochemical facies which are able to provide clues how groundwater quality changes within and between aquifers (Sivasubramanian et al. 2013). From the samples plotting on the Piper (1944), trilinear diagram (Fig. 2) shows that $\mathrm{HCO}_{3}{ }^{-}, \mathrm{Ca}^{2+}$ and $\mathrm{Mg}^{2+}$ play a dominating role for characterizing groundwater, other than $\mathrm{Cl}^{-}$ or $\mathrm{SO}_{4}{ }^{2-}$. The Fig. 2 shows $\mathrm{HCO}_{3}-\mathrm{Ca}-\mathrm{Mg}$ are the major chemical types, clustering at the left corner of the diamond on the plot and confirming the shallow porous groundwater hydrochemistry characteristic in carbonate sediments. The release of $\mathrm{HCO}_{3}{ }^{-}$from rocks weathered by the carbonic acid in rainwater is the important part of carbon cycle. Geologically, the term "carbonate" refers equally to carbonate minerals and carbonate rocks and both are dominated by the $\mathrm{CO}_{3}{ }^{2-}$ ion. Carbonate minerals are enormously varied and everywhere in chemically precipitated sedimentary rock. Preferably, $\mathrm{Ca}^{2+}$ and $\mathrm{Mg}^{2+}$ might have been contributed through dissolution of carbonate minerals (Zhou et al. 2012). The most common are calcite, the chief constituent of limestone (as well as the main component of mollusc shells and coral skeletons); dolomite and siderite, an important iron ore. These water types may have evolved from the dissolution of calcite and dolomite minerals in the rocks according to equations,

$$
\begin{aligned}
& \mathrm{CaCO}_{3}+\mathrm{CO}_{2}+\mathrm{H}_{2} \mathrm{O} \leftrightarrow \mathrm{Ca}^{2+}+2 \mathrm{HCO}_{3}^{-} \quad \text { (calcite) } \\
& \mathrm{CaMg}\left(\mathrm{CO}_{3}\right)_{2}+2 \mathrm{CO}_{2}+2 \mathrm{H}_{2} \mathrm{O} \\
& \leftrightarrow \mathrm{Ca}^{2+}+\mathrm{Mg}^{2+}+4 \mathrm{HCO}_{3}^{-} \quad \text { (dolomite) }
\end{aligned}
$$

However, the $\mathrm{CO}_{3}-\mathrm{HCO}_{3}$ system is apparently the most significant chemical system in natural waters. The vital role of the carbonate system is that it provides the buffering capacity essential for maintaining the $\mathrm{pH}$ of natural water systems, and is responsible in a great measure for the alkalinity of water in the range which is needed by bacteria and other aquatic species.

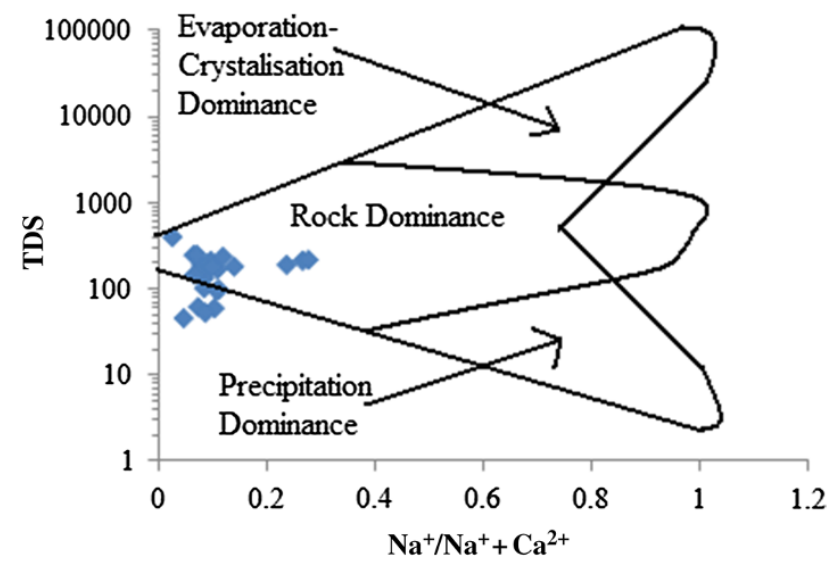

Fig. 3 Gibbs plot showing the mechanism controlling groundwater chemistry of the study area 
Fig. 4 Ionic scatter diagram of groundwater in the study area
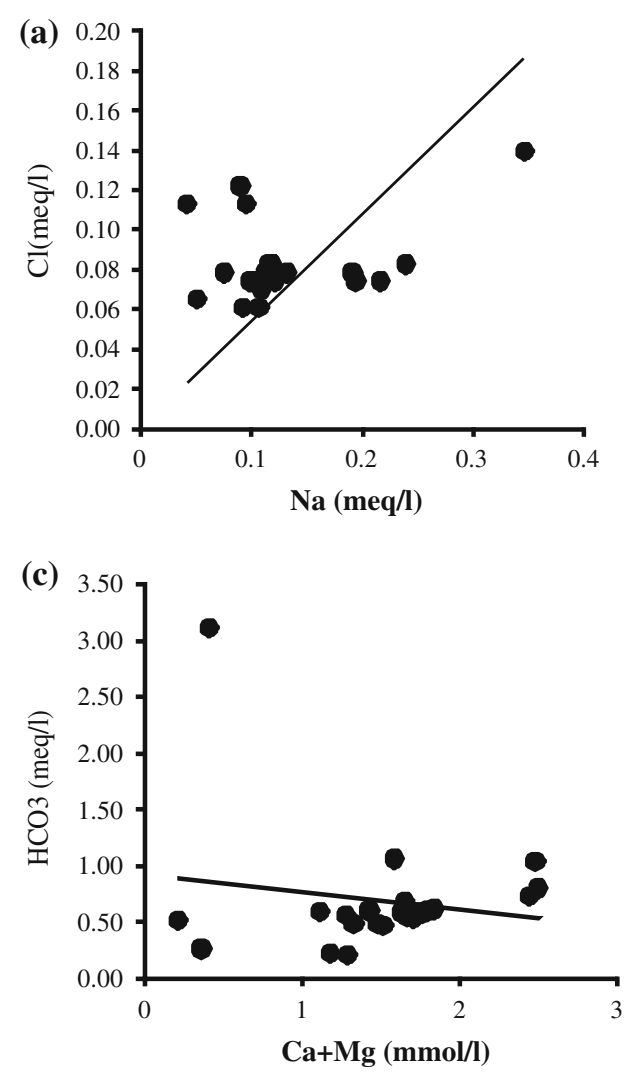
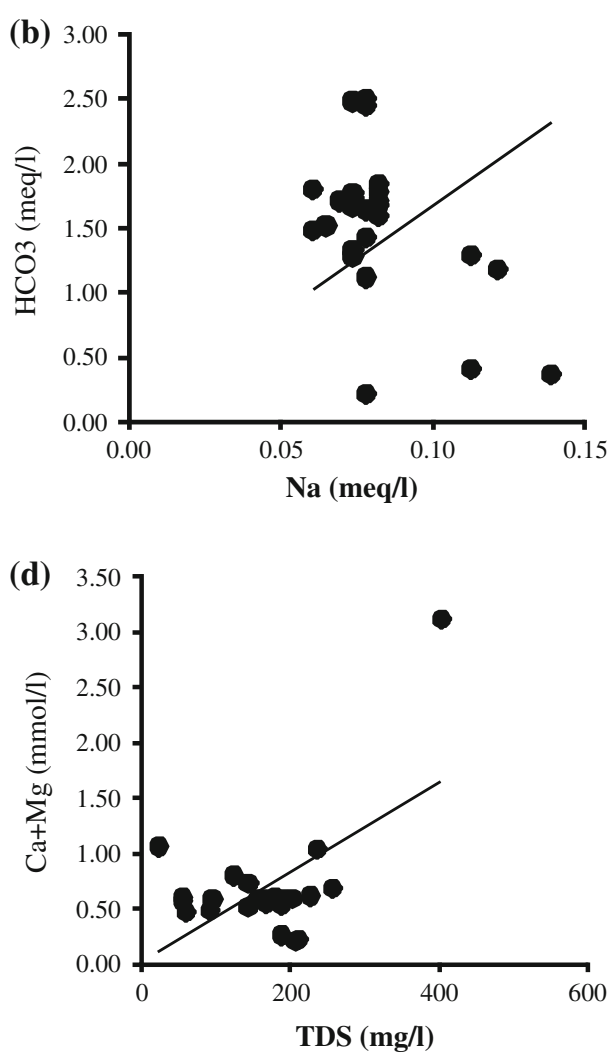

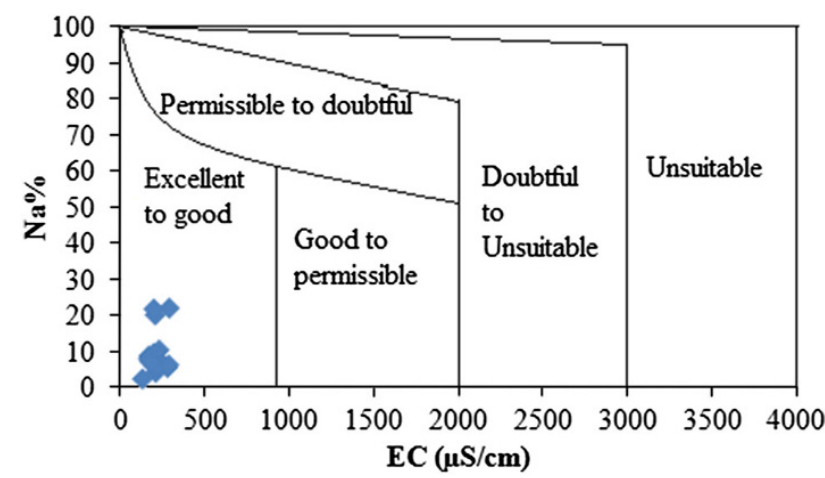

Fig. $5 \mathrm{Na} \%$ vs. EC plots of the groundwater samples of the study area and its suitability for irrigation

In addition to the Piper diagram, Gibbs (1970) plots (Fig. 3) were also employed to gain better insight into hydrochemical processes such as precipitation, rock water interaction and evaporation on groundwater chemistry in the study area. Gibbs (1970) suggested that a simple plot of TDS vs. the weight ration of $\mathrm{Na}^{+} /\left(\mathrm{Na}^{+}+\mathrm{Ca}^{2+}\right)$ (Fig. 3) could provide information on the mechanism controlling the chemistry of waters (i.e., atmospheric precipitation, rock weathering and evaporation and precipitation). The Fig. 3 demonstrates that groundwater samples were plotted both in the rock-dominance zone and precipitation zone, which are influenced by chemical weathering of rock- forming minerals (mostly carbonate minerals). The samples falling in the precipitation dominance are collected from dug wells from the barren areas (area lacking of surface water) of semi-arid climatic condition, which addressed the similar observation of Jeevanandam et al. (2012).

\section{Geochemical process}

The $\mathrm{Na} / \mathrm{Cl}$ is used to identify the mechanism for acquiring salinity, rock-water interaction and saline intrusions (Sivasubramanian et al. 2013). Most water samples plotted close to the line (Fig. 4a) defined by $\mathrm{NaCl}$ showing a continuum from precipitation and uncontaminated groundwater (Panno et al. 1999a). The few samples are exceptions, which contain little $\mathrm{Cl}^{-}$and show an enrichment of $\mathrm{Na}^{+}$because of rock-water interaction within the aquifer (Panno et al. 1994; Hackley 2002) or origin from animal and human waste in rural areas (Panno et al. 1999a). Increased concentration of $\mathrm{Na}^{+}$compared to $\mathrm{HCO}_{3}{ }^{-}$concentration (Fig. 4b) in groundwater suggests that carbonate weathering occurred in the aquifer sediments. The evolution of the slopes of $\mathrm{Ca}^{2+}+\mathrm{Mg}^{2+}$ with $\mathrm{HCO}_{3}{ }^{-}$gives valuable information about the sources of $\mathrm{Ca}^{2+}$ and $\mathrm{Mg}^{2+}$ in groundwater (Richter et al. 1993). $\mathrm{Ca}^{2+}+\mathrm{Mg}^{2+}$ vs. $\mathrm{HCO}_{3}{ }^{-}$plot (Fig. 4c) illustrates a relatively gentle slope line indicating $\mathrm{Ca}^{2+}+\mathrm{Mg}^{2+} / \mathrm{HCO}_{3}{ }^{-}$ ratio reflects some changes during the increase of $\mathrm{HCO}_{3}{ }^{-}$. 
Table 2 Sawyer and McCarthy (1967) classification for groundwater based on hardness

\begin{tabular}{llll}
\hline $\begin{array}{l}\mathrm{TH} \text { as } \\
(\mathrm{mg} / \mathrm{l})\end{array}$ & Water class & $\begin{array}{l}\text { Range } \\
\text { (no. of samples) }\end{array}$ & Percent \\
\hline$<75$ & Soft & 21 Samples & 84 \\
$75-150$ & Moderately hard & 3 Samples & 12 \\
$150-300$ & Hard & Nil & Nil \\
$>300$ & Very hard & 1 Sample & 4 \\
\hline
\end{tabular}

This phenomenon indicates the contribution of $\mathrm{Ca}^{2+}+\mathrm{Mg}^{2+}$ and $\mathrm{HCO}_{3}{ }^{-}$is preferably from dissolution of carbonate minerals and some other sources (Zhou et al. 2012; Sivasubramanian et al. 2013). Higher $\mathrm{HCO}_{3}{ }^{-}$may exist due to the higher evaporation. Enrichment of $\mathrm{HCO}_{3}{ }^{-}$ and depletion of $\mathrm{Ca}^{2+}+\mathrm{Mg}^{2+}$ may be due to cation exchange within the aquifer materials (Spears 1986). The plot of $\mathrm{Ca}^{2+}+\mathrm{Mg}^{2+}$ vs. TDS demonstrates that the data falls on the 1:1 trend line, reflecting $\mathrm{Na}$ and $\mathrm{K}$ as the major contributor for the increase of TDS (Sivasubramanian et al. 2013) (Fig. 4d).

Groundwater quality assessment for irrigation

The suitability of groundwater for irrigation mostly depends on relative concentrations of $\mathrm{EC}$ and $\mathrm{Na}^{+}$in relation to other cations and anions (Todd 1980; Hem 1991). In the studied samples, the groundwater quality was good to excellent for irrigation (Fig. 5).

\section{Total hardness}

Hardness is an important criterion for determining the suitability of groundwater for domestic and industrial uses. The classification of the groundwater of the study area based on hardness (Sawyer and McCarthy 1967) has been carried out and is presented in Table 2. Accordingly, 21 samples $(84 \%)$ fall under the soft class.

\section{Salinity, sodium hazard and SAR}

In order to diagnosis and classification, the total concentration of soluble salts (salinity hazard) in irrigation water can be expressed in terms of specific conductance (Ravikumar et al. 2011). Salinity signifies leaching of salts into groundwater. Salinity hazard (C) has been classified as four groups: (a) low salinity hazard (C1), when the EC is less than $250 \mu \mathrm{S} / \mathrm{cm}$; (b) medium salinity hazard (C2), when it varies from 250 to $750 \mu \mathrm{S} /$ $\mathrm{cm}$; (c) high salinity hazard (C3), when it is in between 750 and $2,250 \mu \mathrm{S} / \mathrm{cm}$; and (d) very high salinity hazard (C4), when it is more than $2,250 \mu \mathrm{S} / \mathrm{cm}$ (Table 3). The values of EC measured from the groundwater samples
Table 3 Quality of irrigation water based on electrical conductivity followed by WHO (2004 standard)

\begin{tabular}{|c|c|c|c|}
\hline $\mathrm{EC}(\mu \mathrm{S} / \mathrm{cm})$ & Water salinity & Samples & $\begin{array}{l}\text { Percent } \\
\text { of } \\
\text { samples }\end{array}$ \\
\hline $0-250$ & $\begin{array}{l}\text { Low salinity } \\
\text { (excellent } \\
\text { quality) }\end{array}$ & $\begin{array}{l}\text { B1-B5, B7-B14, } \\
\text { В16-B22, B24, } \\
\text { B25 }\end{array}$ & 88 \\
\hline $251-750$ & $\begin{array}{l}\text { Medium salinity } \\
\text { (good quality) }\end{array}$ & B6, B15, B23 & 12 \\
\hline $751-2,250$ & $\begin{array}{l}\text { High salinity } \\
\text { (permissible } \\
\text { quality) }\end{array}$ & & \\
\hline $2,251-6,000$ & Very high salinity & & \\
\hline $6,001-10,000$ & $\begin{array}{l}\text { Extensively high } \\
\text { salinity }\end{array}$ & & \\
\hline $10,001-20,000$ & $\begin{array}{l}\text { Brines weak } \\
\text { concentration }\end{array}$ & & \\
\hline $20,001-50,000$ & $\begin{array}{l}\text { Brines moderate } \\
\text { concentration }\end{array}$ & & \\
\hline $50,001-100,000$ & $\begin{array}{l}\text { Brines high } \\
\text { concentration }\end{array}$ & & \\
\hline$>100,000$ & $\begin{array}{l}\text { Brines extremely } \\
\text { high } \\
\text { concentration }\end{array}$ & & \\
\hline
\end{tabular}

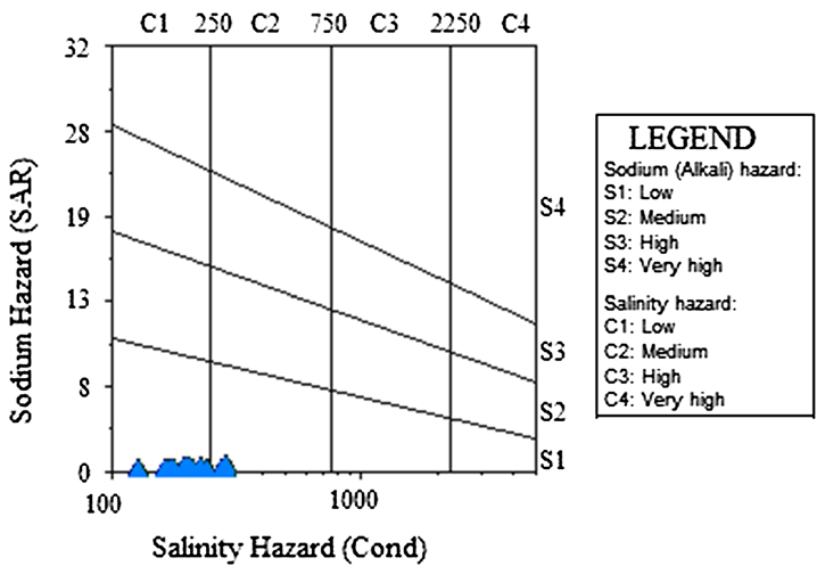

Fig. 6 US salinity diagram showing the sodium adsorption ratio and salinity for the classification of groundwater for irrigation purposes (Wilcox 1948)

vary from 134 to $295 \mu \mathrm{S} / \mathrm{cm}$ (Table 1 ). According to the classification of salinity hazard, most of the groundwater sampling points (Fig. 6) fall in the low (C1) classes for irrigation. The spatial distribution of $\mathrm{EC} \mathrm{(Fig.} \mathrm{7)}$ shows that groundwater salinity increases in the middle and southern part of the basin (especially Sadar Upazila, Paurasava, Salanar and Targun areas). However, some heterogeneity in salinity distribution is observed. The spatial distribution of EC primarily reflects the influence of geology, groundwater residence time and recharge processes on groundwater quality. Hot water spring 


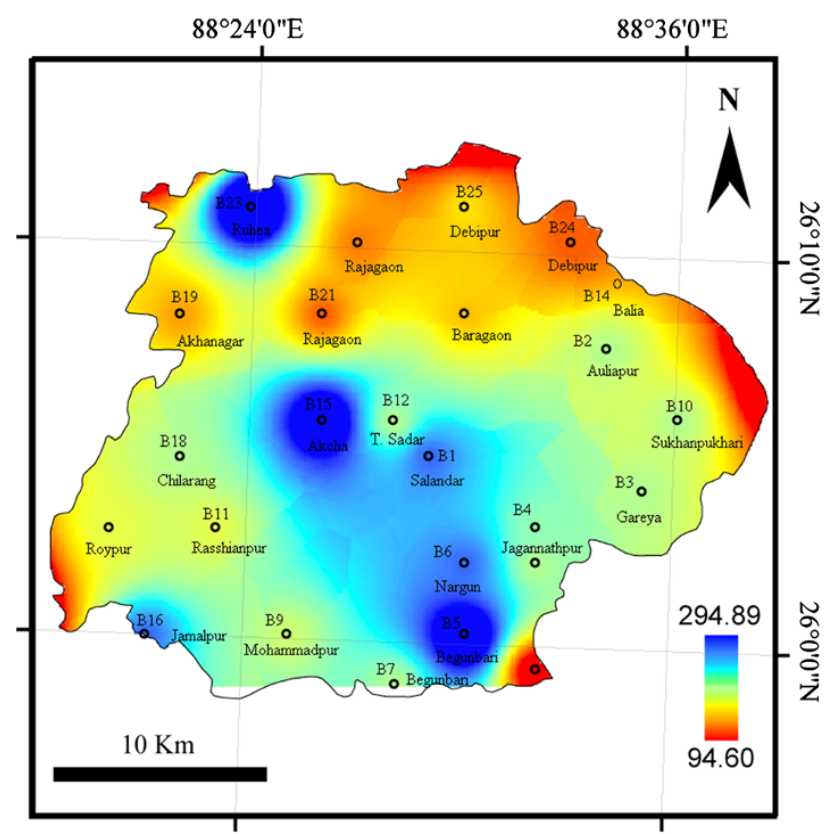

Fig. 7 Spatial distribution of EC (salinity) in groundwater samples in the study area

Table 4 The classification of groundwater for irrigation purpose based on sodium hazard

\begin{tabular}{lllll}
\hline Zone & SAR & Sample no. & \% of samples & Water class \\
\hline S1 & $<10$ & $1-25$ & 100 & Excellent \\
S2 & $10-18$ & - & - & Good \\
S3 & $18-26$ & - & - & Permissible \\
S4 & $>26$ & - & - & Unsuitable \\
\hline
\end{tabular}

(geothermal water) in the southeastern part of the study area influences the salinity level of groundwater. Salinity level showed in the southern part due to infiltration of the upper Tangon River into the aquifer. A higher concentration of EC in the central part of the basin was observed. This is the area acting as the outlet for drainage of upstream land with a shallow water table. In general, a considerable increase in the degree of water mineralization was observed in the direction of Tangon River flow and the least mineralized water was found closest to the main recharge area.

According to the US Department of Agriculture (Wilcox 1955), the Na hazard (S) is classified as (a) low Na hazard (S1), when the SAR is less than 10; (b) medium Na hazard (S2), when it is in between 10 and 18; (c) high Na hazard (S3), when it varies from 18 to 26; and (d) very high $\mathrm{Na}$ hazard (S4), when it is more than 26 (Table 4). The SAR values calculated from the groundwater samples of the study area are in between 0.064 and 0.274 (Table 1), which classified the groundwater samples in the excellent category (S1) for irrigation (Table 4). The higher the SAR

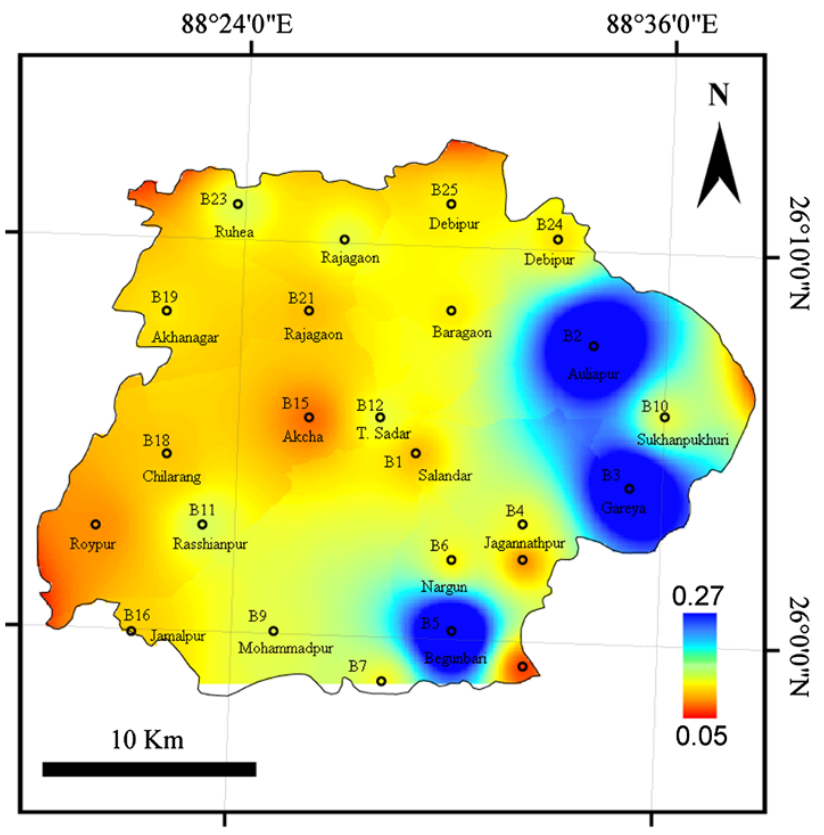

Fig. 8 The distribution of SAR values in the study area

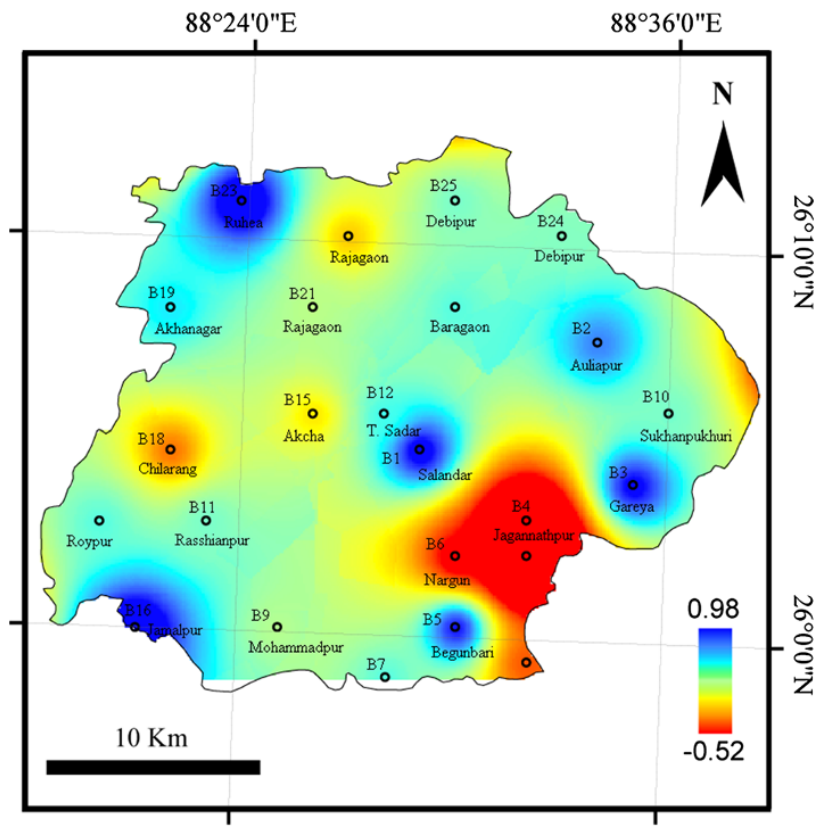

Fig. 9 RSC distribution in the study area

values, the greater is the risk of $\mathrm{Na}$ on plant growth. The distribution of SAR values in the study area is shown in Fig. 8. It is observed that samples of low SAR are mainly located in the northern-western part of the area, while high SAR dominated the southern part. The spatial distributions of EC and SAR showed nearly a similar pattern which dominates in the southern part of the study area (Table 1). However, some heterogeneity was observed in the basin. Variations in SAR are larger in the southeastern part of 


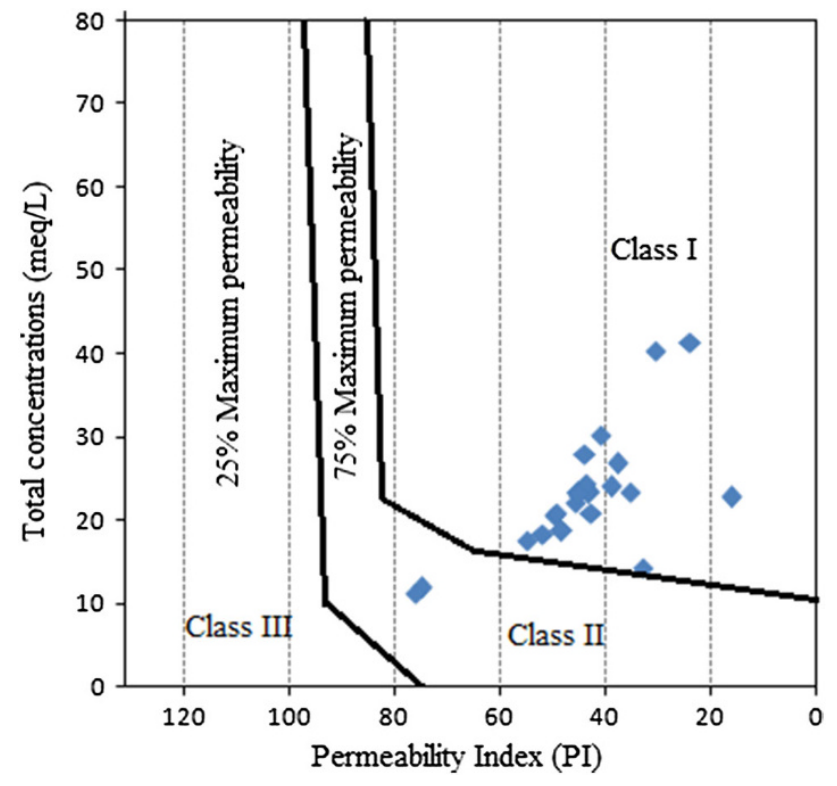

Fig. 10 The permeability index of the groundwater samples in the study area

study area (Fig. 8). Whereas southwestern part of the study area is dominated with higher EC values.

\section{Residual sodium carbonate (RSC)}

A relation of alkaline earths with weak acids is expressed in terms of RSC for assessing the quality of water for irrigation (Richards 1954). When the weak acids are greater than the alkaline earths, a precipitation of alkaline earths occurs in soils, which damages the permeability of soil (Rao et al. 2012). On the basis of RSC values, water quality is generally classified as (a) safe, when the RSC is less than 1.25 milli-equivalents per liter; (b) marginally safe, when it is between 1.25 and 2.50 milli-equivalents per liter; and (c) unsafe, when it is more than 2.50 milliequivalents per liter for irrigation (Richards 1954). The values of computed RSC from groundwater samples of the study area vary from 0.17 to 0.984 (Table 1). Hence, all the groundwater samples are safe for irrigation. Spatial analysis showed that there is no significant variation of RSC distribution in studied samples. The lowest value of RSC was found in the northeastern part (Jaganathpur/Nargun area) of the study area (Fig. 9).

Permeability index

The permeability index of the groundwater samples ranges from 4 to $76 \%$ (Fig. 10) with an average value of $42 \%$. Hence, all the samples fall in class 1 of Doneen's chart (Domenico and Schwartz 1990). WHO (1998) uses a criterion for assessing the suitability of water for irrigation based on the permeability index. According to the permeability index values, $98 \%$ of the samples fall under class 1 (PI $>75 \%$ ) and about $2 \%$ belong to class 2 (PI ranged from 25 to $75 \%$ ) (Fig. 10).

\section{Conclusion}

The quality of groundwater resources in the central Thakurgaon Sadar of Thakurgaon District was evaluated to reconnaissance the suitability for irrigation uses. The order of abundance of ions in groundwater samples are $\mathrm{Ca}^{2+}>\mathrm{Mg}^{2+}>\mathrm{Na}^{+}>\mathrm{K}^{+}$and $\mathrm{HCO}_{3}{ }^{-}>\mathrm{CO}_{3}{ }^{2-}>$ $\mathrm{SO}_{4}{ }^{2-}>\mathrm{Cl}^{-}>\mathrm{NO}_{3}{ }^{-}>\mathrm{F}^{-}$. Trace metals concentration in groundwater samples were below the detection limit. The chemical analyses of groundwater samples indicate that the water is chemically characterized by $\mathrm{Ca}-\mathrm{HCO}_{3}, \mathrm{Ca}-\mathrm{Mg}-$ $\mathrm{HCO}_{3}$ and $\mathrm{CaCO}_{3}$ with low TDS. The groundwaters from these groups are recharged through direct infiltration of rain. However, the groundwater evolution in this study is mainly the result of weathering of carbonate minerals and cation exchange within the aquifer materials, confirming the shallow porous groundwater hydrochemistry characteristics.

Gibbs plots showed that most of the samples fall in rockdominance zone. The evolution of these waters may be controlled by precipitation and dissolution of carbonate minerals. The plot of $\mathrm{Ca}+\mathrm{Mg} / \mathrm{HCO}_{3}$ showed enrichment of $\mathrm{HCO}_{3}$ than $\mathrm{Ca}+\mathrm{Mg}$ suggesting both were from different sources. SAR, RSC, and \% Na imply that the water samples fall in excellent, suitable and safe for irrigation. The $\mathrm{Na}^{+}$hazards in all samples are low, indicating that these waters are suitable for irrigation in almost all soils with small danger of the development of $\mathrm{Na}^{+}$problem. Permeability index of the water samples recommends that the water from the Thakurgaon area, belonging to class 1 is suitable for irrigation. USSL graphical geochemical representation of irrigation water quality suggests that all the samples fall under low salinity with low alkali hazards.

Acknowledgments The first author acknowledges financial support from the Japanese Government (MONBUKAGAKUSHO Scholarship 2007-2010) and the authority of the Department of Earth Sciences, Okayama University, Japan for their technical assistance.

Open Access This article is distributed under the terms of the Creative Commons Attribution License which permits any use, distribution, and reproduction in any medium, provided the original author(s) and the source are credited.

\section{References}

Ayers RS, Westcot DW (1985) Water quality for agriculture, FAO irrigation and Drainage Paper 29, Rev. I, UN Food and Agriculture Organization, Rome 
Bhattacharya P, Jacks G, Ahmed KM, Khan AA, Routh J (2002) Arsenic in groundwater of the Bengal Delta Plain aquifers in Bangladesh. Bull Environ Contam Toxicol 69:538-545

Bhuiyan SI (1984) Groundwater use for irrigation in Bangladesh: the prospects and some emerging issues. Agric Adm 16(4):181-207

Devadas DJ, Rao NS, Rao BT, Rao KVS, Subrahmanyam A (2007) Hydrogrochemistry of the Sarada River basin, Visakhapatnam district, Andhra Pradesh, India. Environ Geol 52(7):133-1342

Domenico PA, Schwartz FW (1990) Physical and chemical hydrogeology. Wiley, New York, pp 410-420

Doneen LD (1964) Notes on water quality in agriculture. Water Science and Engineering, University of California, Davis

FAO (1972) Overall study of the Messara Plain. Report on study of the water resources and their exploitation for irrigation in eastern Crete, 1972, FAO Report No. AGL:SF/GRE/31

Foster SSD (1995) Groundwater for development-an overview of quality constraints. In: Nash H, McCall GJH (eds) Groundwater Quality. 17th Special Report. Chapman and Hall, London, pp 1-3

Freeze RA, Cherry JA (1979) Groundwater. Prentice Hall, Englewood Cliffs

Gaus I, Kinniburgh DG, Talbot JC, Webster R (2003) Geostatistical analysis of arsenic concentration in groundwater in Bangladesh using disjunctive kriging. Environ Geol 44:939-948. doi:10. 1007/s00254-003-0837-7

Gibbs RJ (1970) Mechanisms controlling world water chemistry. Science 170(3962):1088-1090

Hackley KC (2002) a chemical and isotopic investigation of the groundwater in the mahomet bedrock valley aquifer: age, recharge and geochemical evolution of the groundwater. Ph.D.Thesis, University of Illinois, Urbana-Champaign. p 152

Harris DC (1991) Quantitative chemical analysis. (3rd edn) Freeman, New York, US EPA method 340.2

Hem JD (1985) Study and interpretation of the chemical characteristics of natural water, 3rd edn. Scientific Publishers, Jodhpur, p 2254

Hem JD (1991) Study and interpretation of the chemical characteristics of natural waters, Book 2254, 3rd edn. Scientific Publishers, Jodhpur

Jeevanandam M, Nagarajan R, Manikandan M, Senthilkumar M, Srinivasalu S, Prasanna MV (2012) Hydrogeochemistry and microbial contamination of groundwater from Lower Ponnaiyar Basin, Cuddalore District, Tamil Nadu, India. Environ Earth Sci 67(3):867-887

Kelly WP (1940) Permissible composition and concentration of irrigated waters. In: Proceedings of the ASCF66, p 607

Kumar M, Ramanathan AL, Bhishm R, Kumar MS (2006) Identification and evaluation of hydrogeochemical processes in the groundwater environment of Delhi, India. Environ Geol 50(7):1025-1039

LGRD (2002) Report of the groundwater task force, Ministry of Local Government, Rural Development \& Co-operatives, Local Government Division, Government of the People's Republic of Bangladesh

Matthess G (1982) The properties of groundwater. Wiley, New York, p 498

Michael JT (1975) Water analysis. In: Welcher FJ (ed) Standard methods of chemical analysis (Part B), 6th edn. Robert E. Krieger Publishing Co. Inc, Huntington

Mondal NC, Saxena VK, Singh VS (2008) Occurrence of elevated nitrate in groundwaters of Krishna delta, India. African J Environ Sci Tech 2(9):265-271

Mondal NC, Singh VP, Singh VS (2011) Hydrochemical characteristic of coastal aquifer from Tuticorin, Tamilnadu, India. Environ Monit Assess 175:531-550. doi:10.1007/s10661-010-1549-6
Panno SV, Hackley KC, Liu C-L, Cartwright K (1994) Hydrochemistry of the Mahomet Bedrock Valley Aquifer, east-central Illinois: indicators of recharge and ground-water flow. Groundwater 32(4):91-604

Panno SV, Hackley KC, Greenberg SE (1999a) A possible technique for determining the origin of sodium and chloride in natural waters: preliminary results from a site in northeastern Illinois. (Abstract) in Environmental Horizons 2000, Conference Proceedings, p 57

Piper AM (1944) A graphic procedure in the geochemical interpretation of water analyses. Am Geophys Union Trans 25(12):914-923

Ragunath HM (1987) Groundwater. Wiley Eastern, New Delhi, p 563

Rao NS, Subrahmanyam A, Kumar SR, Srinivasulu N, Rao GB, Rao PS, Reddy GV (2012) Geochemistry and quality of groundwater of Gummanampadu sub-basin, Guntur District, Andhra Pradesh, India. Environ Earth Sci 67(5):1451-1471

Ravikumar P, Somashekar RK, Angami M (2011) Hydrochemistry and evaluation of groundwater suitability for irrigation and drinking purposes in the Markandeya River basin, Belgaum District, Karnataka State, India. Environ Monit Assess 173(1-4):459-487

Richards LA (US Salinity Laboratory) (1954) Diagnosis and improvement of saline and alkaline soils. US Department of Agriculture hand book, p 60

Richter BC, Kreitler CW, Bledsoe BE (1993) Geochemical techniques for identifying sources of groundwater salinization. CRC, New York, p 272

Sanford W, Langevin C, Polemio M, Povinec P (2007) A new focus on groundwater-seawater interactions, vol 312. IAHS Publications, UK. ISBN 978-1-901502-04-6

Sawyer GN, McCarthy DL (1967) Chemistry of sanitary engineers, 2nd edn. McGraw Hill, New York, p 518

Selvam S, Manimaran G, Sivasubramanian P (2013) Hydrochemical characteristics and GIS-based assessment of groundwater quality in the coastal aquifers of Tuticorin corporation, Tamilnadu, India. Appl Water Sci 3:145-159

Shyu GS, Cheng BY, Chiang CT, Yao PH, Chang TSK (2011) Applying factor analysis combined with kriging and information entropy theory for mapping and evaluating the stability of groundwater quality variation in Taiwan. Int $\mathbf{J}$ Environ Res Public Health 8:1084-1109

Simsek C, Gunduz O (2007) IWQ Index: a GIS-integrated technique to assess irrigation water quality. Environ Monit Assess 128(1-3):277-300

Sivasubramanian P, Balasubramanian N, Soundranayagam JP, Chandrasekar N (2013) Hydrochemical characteristics of coastal aquifers of Kadaladi, Ramanathapuram District, Tamilnadu, India. Appl Water Sci 3:603-612

Skoog DA, Leary JJ (1992) Principles of instrumental analysis, 4th edn. Saunders, New York

Spears DA (1986) Mineralogical control of the chemical evolution of groundwater. In: Trudgill ST (ed) Solute processes. Wiley, Chichester, p 512

Todd DK (1980) Ground water hydrology. Wiley, New York

WHO (1998) Guidelines for drinking-water quality. 2nd edn. Addendum to Vol 1-2

WHO (2004) Guidelines for drinking water quality. Revision of the 1993 guidelines. Final Task Group Meeting Geneva, 21-25 September, 1992

Wilcox LV (1948) The quality of water for irrigation use, US Department of Agriculture Circular No. 962, Washington, p 40

Wilcox LV (1955) Classification and use of irrigation waters. US Department of Agriculture Circular, p 969

Zhou T, Wu J, Peng S (2012) Assessing the effects of landscape pattern on river water quality at multiple scales: a case study of the Dongjiang River watershed, China. Ecol Indic 23:166-175 